\title{
Internship Evaluation from the Perspective of Technological University Students in Taiwan
}

\author{
Yi-Hui Chiang \\ Department of International Business \\ Chung Hua University \\ Hsinchu, Taiwan \\ email:yihui@chu.edu.tw
}

\author{
Tan-Fen Huang \\ Institute of Management \\ Minghsin University of Science and Technology \\ Hsinchu, Taiwan \\ email:pink.tiffany@msa.hinet.net
}

\begin{abstract}
Recently senior technological university students are asked whether they are going to choose an internship course or not. What is the key determinant considered by them? Do the incentives provided by the enterprise and school work? The aim of the paper is to propose an internship evaluation model by Analytic Hierarchy Process (AHP) method, from the technological university students' view in Taiwan. The results indicate that the incentives provided by the enterprise and school do matter. Such an internship evaluation model could serve as a decision-making mechanism for the schools, students and enterprises.
\end{abstract}

Keywords- Internship; Analytic Hierarchy Process (AHP); technological university students

\section{INTRODUCTION}

As Taiwan's high education is growing, entering into college or university is not a dream come true: graduation from college or university is not a guarantee of employment. Related working experience before graduation is another helpful aspect in obtaining employment. Therefore, many vocational school and technological universities have established relationships with industrial firms to offer internship opportunities to students. These internship courses place students within the firms where they take part in the commercially productive activities of the enterprise. This kind of cooperation, known as "student internship outside school of course" in Taiwan, provides students the opportunity to work hands on, help them accumulate practical experience in the appropriate enterprises, equip them with capabilities over and above the academic qualifications to be valuable productive members of contemporary society after graduation. In addition to creating an advantage to the students, internship also benefits employing enterprises and sponsoring schools. In view of this, the Ministry of Education (MOE) in Taiwan has established "student internship outside school" as an important policy, and encouraged technological university schools to add internship courses since March of 2009. The internship regulation based on this policy helps schools and enterprises understand the process and gives directions towards running a coordinated internship course.

Researches and surveys on student internship have predated its application in Taiwan. Literature reviews show that most studies recognize the positive effects of student internship [1-5], and some emphasize its negative effects [6,7]. Some authors also focus on the performance of student internship [811]. However, little attention is paid to the discussion and evaluation of a student internship course, from the technological university students' view.

All in all, issues concerning internship are diverse and this topic is not only emphasized by the school, but also by the industry and by government. Exploring this issue involves the factors to be dealt with by the previously mentioned parties: when there are at least three objectives it can be classified as a Multiple-Criteria-Decision-Making (MCDM) problem. MCDM techniques have been used in recent years to solve a variety of decision-making problems involving evaluating and selecting multiple criteria among alternatives. The practical applications reported in the literature have shown advantages in handling quantitative and qualitative data with this technique, and they have obtained pretty reliable results [12-14]. This study applies the Analytic Hierarchy Process (AHP) to develop an evaluation model on the student internships decision from the technological university student's point of view. The results provide a reference for school, students and the enterprises.

According to the result, the weight ranking of the evaluating dimensions of student internship is: (1) Enterprise factors; (2) Financial factors; (3) School factors and (4) Nonfinancial factors. Among the 20 criteria, the top three as ranked by the respondents are "the enterprises provide salary"; "approving the internship report equal to special topic report" and "the provided internship work that fits me". The results indicate that the incentives provided by enterprise (salary) and by school (approving the internship report equal to special topic report and credit points) do matter. This paper is organized as follows. Section 2 proposes an internship evaluation model and Section 3 presents the result of case study. Finally, conclusions are drawn from the findings.

\section{AN INTERNSHIP EVALUATION MODEL}

The Analytic Hierarchy Process (AHP) is a tool decision analysts use to aid decision makers in making multi-criteria decisions. Based on a review of previous studies, we initially chose more than 25 relevant factors. Factor items with a low loading were then deleted by using a 7-point Likert scale. The key dimensions of the criteria for internship determinants were derived through consulting with 12 representative experts who had experience with internship counseling, mentoring and supervision. These experts included 5 professors and 7 students 
who had internship experience ranging from 6 to 12 months. These individuals were asked to rate the accuracy, adequacy, and relevance of the criteria and dimensions and to verify their content validity in terms of considering whether to choose an internship course. They identified four main aspects of importance for "student internship outside school of course" and which had to be included in the analysis: enterprise factors, financial factors, non-financial factors, and school factors. To reach an adequate level of detail in the analysis, these four dimensions were further divided such that each included 5 criteria.

\section{A CASE STUDY ON M TECHNOLOGICAL UNIVERSITY}

\section{A. Background}

Taking $\mathbf{M}$ technological university for example, internship courses all belong to elective course. Students usually choose an internship course during the third or fourth year in campus. After completing the 6 months or 960 working hours of internship, the interns obtain 9 elective credits points. In order to courage the program, many departments of management institute approving the internship report to equal special topic report (which is an obligatory course). To help us investigate students' viewpoints on "Student internship outside school", 48 students completed the questionnaire among the 60 students from the institute of management in $M$ university in Taiwan. After an initial examination of the data, three further responses were deleted for C.I. >1. Thus, 45 usable surveys were collected. A valid response rate is $75 \%$. The research period covered is from 2011/08 to 2012/02. The respondents had all chose and joined the internship course for the first time.

\section{B. Data Collections}

The demographic profile and description of the 45 surveys is as follows:

(1) Sex: the number of males is $21(47 \%)$ and 24 are females $(53 \%)$.

(2) Age: the respondents are all senior students and their age is about 21-22.

(3) Department: the number of IB is $15(33 \%)$, B A is $6(13 \%)$, FM is $9(20 \%), \mathrm{IM}$ is $8(18 \%)$ and IEM is (16\%).

(4) Industry: the number of students who did their internship work in the service industry is $28(62 \%)$, and the number in technological industry is $17(38 \%)$.

(5) Working hours per day: 9 students $(20 \%)$ worked 7 hours, $21(47 \%)$ worked 8 hours and $15(33 \%)$ did 9-10

(6) Did they retain a desire to do the same kind of work as during internship after graduation? 21 answered "Yes" and 24 "No".

\section{RESULTS AND DISCUSSIONS}

The weight of the response obtained from each surveyed respondent is calculated by Expert Choice 9.5 (2005)[15]. The rank of dimension and criteria within the complete evaluation criteria hierarchy is also obtained. The average C.I. of weight factors of evaluation dimensions $(\mathrm{C} 1, \ldots, \mathrm{C} 4)$ and criteria across dimensions $(\mathrm{C} 11, \ldots, \mathrm{C} 45)$ is 0.036 and 0.047 , respectively; that is, C.I. $<0.1$, indicating that the judgment of consistency index is satisfied. The weight factors and rank of the 20 evaluation criteria from the surveyed respondents are listed in Table 1.

The results are described as follows. The weight factors affecting the dimensions of evaluating the student internship course are: (1) Enterprise factors $(\mathrm{C} 1=0.279)$; (2) Financial factors $(\mathrm{C} 2=0.260)$; (3) School factors $(\mathrm{C} 4=0.252)$ and; (4) Non-financial factors $(\mathrm{C} 3=0.209)$. This result indicates that for the respondents, "Enterprise factors" is the key dimension, while "Non-financial factors" is the least important dimension when they evaluate whether to join the student internship program or not. Among the 20 criteria, the respondents rank "the enterprises provide salary" $(\mathrm{C} 21=0.076)$ as the most important; "approving internship report to be equal special topic report" $(\mathrm{C} 45=0.064)$ the second important; "the provided internship work fits me" $(\mathrm{C} 11=0.060)$ is ranked the third important criteria; while "the enterprises provide lodging or subsidy" $(\mathrm{C} 24=0.034)$ is ranked the last. The results indicate that salary, special topic report or credit points, and the aptness of internship work are the three most important factors considered by the student respondents when they evaluate whether joining the internship course or not.

\section{CONCLUSION}

The aim of the paper is to study the evaluation on internship decision from the students' view. Based on the above results, we draw the following conclusions: according to the result of AHP, salary, get credit points of obligatory courses or elective courses, and the fitness of internship work are the most important factors considered by the student respondents when they evaluate joining the internship program. That is, the incentives provided by enterprise (salary) and by school (approving the internship report equal to special topic report and credit points) do matter.

In the past, when asked why a student chooses to join an internship course, most students' answers would have depended on their experience, knowledge, and information, which is difficult to define or describe precisely. Most previous research studies have focused only on the motivation and benefit, paying little attention to the behaviour of student interns from an integrated perspective. This study develops an internship evaluation model using a combination of subjective and objective criteria. This approach contributes to the literature by providing an aggregate, comprehensive, and scientific framework for evaluating student interns' behavior on internship courses. This framework provides a reference for the decision-maker when evaluating an internship course where there are many variables. We encourage further research applying our model to other internships from different departments or schools, so as to better understand the practice, thereby obtaining more generalized suggestions for students, enterprises and schools - when all three of the sides are involved. 


\begin{tabular}{|c|c|c|c|c|}
\hline Dimension/ Criteria & $\begin{array}{l}\text { weight of } \\
\text { dimension }\end{array}$ & $\begin{array}{l}\text { weight of } \\
\text { criteria }\end{array}$ & $\begin{array}{l}\text { ranking of } \\
\text { dimension }\end{array}$ & $\begin{array}{c}\text { ranking of } \\
\text { criteria }\end{array}$ \\
\hline$\overline{C_{1} \text { Enterprise factors }}$ & 0.279 & & (1) & \\
\hline$C_{11}$ the provided internship work that fits me & & 0.060 & & (3) \\
\hline$C_{12}$ good reputation of the enterprise & & 0.054 & & (8) \\
\hline$C_{13}$ convenient location of the workplace & & 0.056 & & (7) \\
\hline$C_{14}$ good environment of the workplace & & 0.057 & & (6) \\
\hline$C_{15}$ could retain the position after graduation & & 0.051 & & (9) \\
\hline$C_{2}$ Financial factors & 0.260 & & (2) & \\
\hline$C_{21}$ the enterprises provide salary & & 0.076 & & (1) \\
\hline$C_{22}$ the enterprises provide labor related insurance & & 0.051 & & (10) \\
\hline$C_{23}$ the enterprises provide board or subsidy & & 0.040 & & (16) \\
\hline$C_{24}$ the enterprises provide lodging or subsidy & & 0.034 & & (20) \\
\hline$C_{25}$ the enterprises provide other bonus & & 0.059 & & (5) \\
\hline$C_{3}$ Non-financial factors & 0.209 & & (4) & \\
\hline$C_{31}$ get the realistic world preview of enterprises & & 0.034 & & (19) \\
\hline$C_{32}$ gain the real world work experience & & 0.049 & & (11) \\
\hline$C_{33}$ gain mentoring and assistance & & 0.038 & & (18) \\
\hline$C_{34}$ gain communication and teamwork skill training & & 0.044 & & (13) \\
\hline$C_{35}$ understand capability oneself & & 0.044 & & (14) \\
\hline$C_{4}$ School factors & 0.252 & & (3) & \\
\hline$C_{41}$ evaluation of internship work in the enterprise & & 0.039 & & (17) \\
\hline$C_{42}$ provision of counseling, guidance and assistance & & 0.046 & & (12) \\
\hline$C_{43}$ provision of student safety insurance & & 0.042 & & (15) \\
\hline$C_{44}$ getting credit points for completing specific internship hours & & 0.060 & & (4) \\
\hline$C_{45}$ approving the internship report to be equal special topic report & & 0.064 & & (2) \\
\hline
\end{tabular}

\section{REFERENCES}

[1] Clithero, J. B. and Levenson, L. A., Successful internship requires appropriate interaction between school, firm and students. Marketing Educator. 5 (1986) 3.

[2] Beard, F. D., The status of internships: Cooperative education experiences in accounting education. Journal of Accounting Education. 16 (1988) 506-516.

[3] Rainsbury, E. and Hodges, D. Sutherland and Barrow, M., Academic, employer and student collaborative assessment in a work-based cooperative education. Assessment and Evaluation in Higher Education. 23 (1998) 313-324.

[4] Lam, T. and Ching, L., An exploratory study of an internship program: The case of Hong Kong students. Hospitality Management. 26 (2007) 336-351.

[5] Zuhal P., Selçuk U., Nuriye Ç., Ayse Ç., Necla T., Bekir O., Gülhan, B., Leyla U. and Demet Ö., Internship education analysis of vocational school students. Procedia Social and Behavioral Sciences. 2 (2010) 3456.

[6] Pavesic, D. and Brymer, R. A., Job satisfaction: what's happening to the young managers? Cornell Hotel and Restaurant Administration Quarterly. 30 (1990) 90-96.

[7] Fox, T., A sense of place. Caterer and Hotelkeeper, 189 (4160), 2001.

[8] Beebe, A., Blaylock, A. and Sweetser, K. D., Research in brief Job satisfaction in public relations internships. Public Relations Review. 35 (2009) 156-158.

[9] Fall, L., Value of engagement: Factors influencing how students perceive their community contribution to public relations internships. Public Relations Review. 32 (2006) 407-415.

[10] Zhao, H., Turning small business interns into applicants: The mediating role of perceived justice. Journal of Business Venturing. 28 (2013) 443457.

[11] Feldman, C. D. and Bolino, C. M., Skill utilization of overseas interns: antecedents and consequences. Journal of International Management. 6 (2000) 29-47.
[12] Chiang, Y. H. and Hung, C. Y., Trade credit evaluation for the broadband communications manufacturing industry in Taiwan. International Journal of Management and Decision Making.11 (2010) 37-54.

[13] Hsieh, T.Y., Lu, S.T. and Tzeng, H.G., Fuzzy MCDM approach for planning and design tenders selection in public office buildings. International Journal of Project Management. 22 (2005) 573-584.

[14] Tzeng, G. H., Teng M. H., Chen J. J. and Serafim O., Multicriteria selection for a restaurant location in Taipei. Hospital Management. 21 (2002) 171-187.

[15] Expert Choice User's Guide (2005) Version 11. Expert Choice, Inc. 